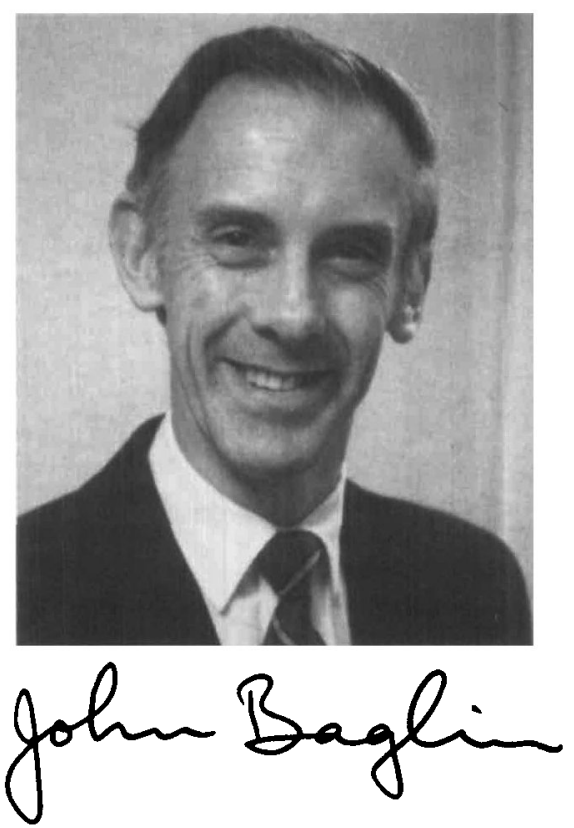

Election Day in the United States is fast approaching. As in every election, this will be the time when the seeds are sown for far-reaching actions of government, whose policies will have powerful short-range and long-range effects on the well-being of the United States and indeed of the world. In this letter I would like to remind you of some of the important issues which significantly affect materials research, and issues which deserve the contribution of materials people in informed debate. There has never been a more important time for engineers and scientists to take the initiative and discuss these issues with their candidates, capture their attention and interest, and establish lines of communication that may later continue right into the legislature. Now is the time for your opinions to be heard, and I urge you to consider how you can personally take a constructive part in this election.

I do not mean to direct this letter only to U.S. voting members of the Materials Research Society. I believe many similar issues will be found to be equally important in every nation where materials researchers may choose to contribute to their national and local decision-making processes.

Is your candidate knowledgeable on materials issues and materials research? Is he or she willing to listen and capable of grasping technical matters? Do they care? Can you encourage them to care?

In the spirit of stimulating action, I am going to list some topics that occur to me as ripe for discussion. I urge you to add your own and to act with such issues in mind.

\title{
Voting for
Research
}

Funding for Materials Research

Government avenues of materials research funding include support of national laboratories and government laboratories, and contracts with universities and industry. Is the overall commitment large enough to sustain the nation's technical and academic good health? Should the shift of emphasis towards technology development continue? Are funding decisions made with adequate technical understanding and consultation? How should the conflicting claims of "big science" vs. "small science" be resolved in the area of materials? Materials research has become one of the fastest growing disciplines of our time, representing as it does an orderly convergence of the traditional disciplines, in which chemistry, physics, metallurgy, engineering, geosciences, biosciences, etc., are combined in the discovery, understanding and development of new advanced materials and processes. Does research funding distribution properly reflect the power and potential of materials research today?

\section{Environment for Industrial \\ Research}

Industrial investment in materials research, especially at a fundamental level, is notoriously vulnerable to the financial climate. Only the most enlightened and secure corporations can maintain a large commitment to long-term basic research in the face of pressures to show short-term returns in periods of economic difficulty. Yet neglect of basic research must jeopardize innovative technological competitiveness five or ten years hence. Should government be creating fresh economic incentives for industries to make larger, more confident investments in materials research and development?

\section{Responsible Technical Consultation}

This is an age in which an ever increasing proportion of all the decisions of government (including major policy decisions) deal with advanced technologies and their applications. Examples are evident in nuclear power, defense technology, toxic waste management, communications systems, and aerospace programs. Many legislators and their staffs and committees today make valiant efforts to weigh the technical issues properly in drafting and assessing new legislation. Responsible decision-making by a legislator whose background is not technical (like the majority) must surely demand diligent consultation with responsible scientists and engineers and an awareness of current research trends. In the interest of soundly based legislation of the future it must surely be important to establish a candidate's willingness to become well informed on technical aspects of new legislation, and to properly respect their significance. Will the candidate's staff include a capable scientist or engineer who can interact effectively with the materials community, know the questions to ask, and know whom to ask?

\section{Professional Organizations}

It is important for legislators to be made aware of the activities, service goals and needs of technical/professional societies such as MRS. Our meetings, publications, etc., constitute very substantial support for the entire materials community, delivered highly effectively at low cost. Our "501c(3) not-forprofit" tax-exempt status helps make it possible for us to provide services at reasonable costs. However, governments have shown a fascination with finding ways to reduce the benefits for $501 \mathrm{c}(3)$ organizations, most recently proposing to extend the definition of taxable unrelated business income and attempting to end our access to special bulk mailing rates. Such concessions were set up to allow the "not-forprofits" to do a better job of public service, and they need to be defended.

\section{Education}

Through programs such as the National Science Foundation's Undergraduate Faculty Enhancement Program, the federal government is taking positive steps to enhance the breadth and quality of education available to students in the engineering and scientific disciplines. Other kinds of support (laboratory facil- 
ities, student subsidies, library and computer funding) are also needed at levels not seen in the past in order to ensure that the scientists and engineers of tomorrow will have received quality instruction using state-of-the-art equipment. The same kind of support can be even more significant when applied in the teaching of the sciences to students with nontechnical majors, for whom this may prove to be their one-time preparation for responsible participation in a highly technical world.

At the graduate level, the needs for research support are even greater if student researchers are to be given the best opportunity to attack forefront problems. This is especially significant in the newer materials disciplines, where state-of-the-art instrumentation is expensive and competition is intense.

Will your candidates be alert to the nation's needs for more graduating researchers of high quality to sustain the nation's technical progress, industrial competitiveness and sound resource management? Do your candidates appreciate the educational issues involved?

\section{Public Information}

If a community is to take best advantage of the age of advanced technology and science, then its members must either develop their own basic understanding of technical issues, or abandon to "the experts" the technical decisions that will dominate their lives. Continuing public education in technical and engineering questions can help resolve this problem and it can be addressed at all levels, ranging from professional short courses and advanced college programs to responsible production of popular science literature and documentary thought-provoking radio and television series. Such radio features have been made by the American Institute of

\section{for accurate determination of thermal expansion count on RECORTON AUTOMATIC}

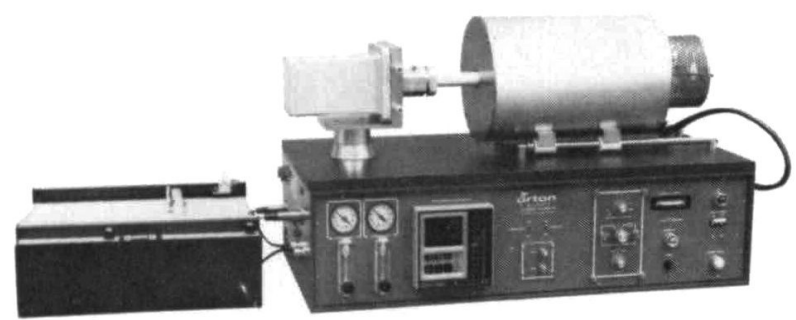

Orton Dilatometers are laboratory calibrated for accuracy against CP platinum to help insure precise measurement of thermal length changes (expansion and/or shrinkage) of ceramics, plastics, metals and glass. A wide range of models and options are available for applications including:
- Process and Quality Control raw material control control of process factors

- Service Condition Evaluation determine behavior in service analyze failures in service
Materials and Composition R\&D evaluate compatibility of composites determine effects of material changes

\section{- Process R\&D} determine control factors determine optimum process conditions

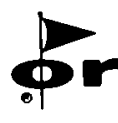

The Edward Orton Jr. Ceramic Foundation

6991 Old 3C Highway • P.O. Box $460 \bullet$ Westerville, Ohio 43081-0460 $800-848-3983 \cdot 614-895-2663$
Physics and by the American Chemical Society, for example. Television series such as "Nova" have similar goals.

Such enterprises are excellent but very expensive, and their production and airing require substantial funding drawn from private, commercial, and government sources. Does your candidate regard such funding as a good investment? Does he or she want to work towards informed public debate of the weighty materials issues and advanced engineering decisions of our time?

\section{International Forum}

MRS can point with confidence to one of the key qualities that has always distinguished our technical meetings and greatly contributed to their success. That quality is the lively participation by researchers from many different parts of the world, whose different perspectives, different motivations, different goals and special insights so greatly enrich the technical discussion and vitality of the symposia. This Fall, we expect to see the formal emergence of an international organization of materials research societies from various nations, which has evolved with the theme of fostering international cooperation and the advancement of materials research in all its aspects. Its charter will be developed having in mind the long standing examples of IUPAP and IUPAC in the worlds of physics and chemistry.

The research community clearly values such interactions highly, with good reason. Will your candidate recognize and respect this in framing government policies on international technical interactions? Will he or she recognize the potential of such international organizations to contribute uniquely to cooperative programs in new materials, world resource management, and education?

Although I have tried to raise questions rather than propose the answers, I have no doubts that, despite my best intentions, I have walked on some political toes in this letter. If they were your toes, I do apologize, and ask you to look beyond the detail to my broad aim to stimulate ideas, whatever those ideas might be. I must also emphasize that these words are mine alone, and not necessarily endorsed by the Materials Research Society or its officers and members. In conclusion, if your political toes are not hurting, let me urge you to take the next steps..... 


\section{$M|R| S$ Treasurer's Report}

I am pleased to present the following annual Statement to Members on the financial health of the Materials Research Society. My statement is based on the auditor's reports prepared by our accountants, Martin R. Bujaky \& Associates, Certified Public Accountants, Pittsburgh, for the years ending December 31, 1987 and 1986. The basic financial information may be found on the following page in the tabulated material entitled Financial Statements and Statements of Revenues, Expenses, and Changes in Fund Balance.

The Materials Research Society continues to grow vigorously. Some numerical indicators of this growth are shown in Table l. It is notable that, each year, a greater proportion of members begin or renew their memberships individually, i.e., separately from attendance at a meeting. This indicates that MRS is developing an ongoing membership base which transcends the technical program at a given meeting. The annual budget has increased by approximately $\$ 0.5$ million each of the last four years, reflecting major new initiatives in Society activities and member services.

A picture of the inward and r.jtward flow of dollars is given by the revenue and expense pie charts in Figures 1 and 2. The Materials Research Society's primary focus continues to be the technical meetings and their associated activities. Since 1984 two annual meetings have been held, in the Spring and the Fall, in response to the increasing demand for symposia covering new and diverse topics in forefront materials research. MRS is its own publisher of symposium proceedings and presently publishes approximately 30-35 volumes a year, along with proceedings from selected co-sponsored meetings. The short course program and the equipment show are important activities associated with the meetings. The short course program expanded in 1986 to include the Spring meeting, while the equipment show did so in 1987. At the present time grants and corporate sponsors primarily support technical symposia; the Corporate Affiliate program, included in the same sector of the chart, supports other activities of special significance such as the Graduate Student Awards program. Both the Journal of Materials Research and the MRS BULLETIN continue to develop, especially technically. In 1988 the BULLETIN has expanded to 12 issues annually, and later this year publication of JMR will be transferred to MRS Headquarters. Both fine publications are expected to break even within a few years. Headquarters staff and operations expenses are apportioned into the other activity areas in Figure 2.

Overall, the financial health of the Society is good. MRS maintains financial reserves, which I manage and report on regularly to Council. These reserves have been augmented every year. The fact that reserves are growing more slowly than the budget reflects the growtl ! and addition, each year, of expanded and new Society activities which may not initially generate net revenue. In that sense, it is a sign of a vigorous, growing Society. Our reserves should be adequate to get through moderately difficult times, should they occur, and still hold the line on meeting registration fees and proceedings costs, which members see most directly. For the longer term, Council has designated a portion of the reserves to provide a basis for long-range projects such as an expanded awards program or the possible eventual purchase of a Headquarters building. In addition, the Long Range Planning Committee is working on a comprehensive five-year plan to consider trends, goals, and balance among the many Society activities.

Respectfully submitted,

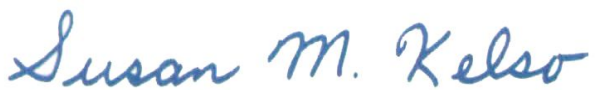

Susan M. Kelso, Treasurer 


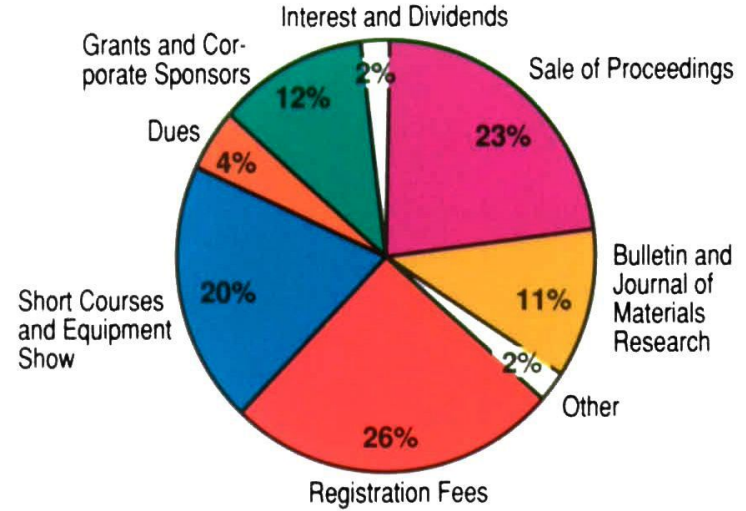

Figure 1. 1987 MRS Revenue Sources.

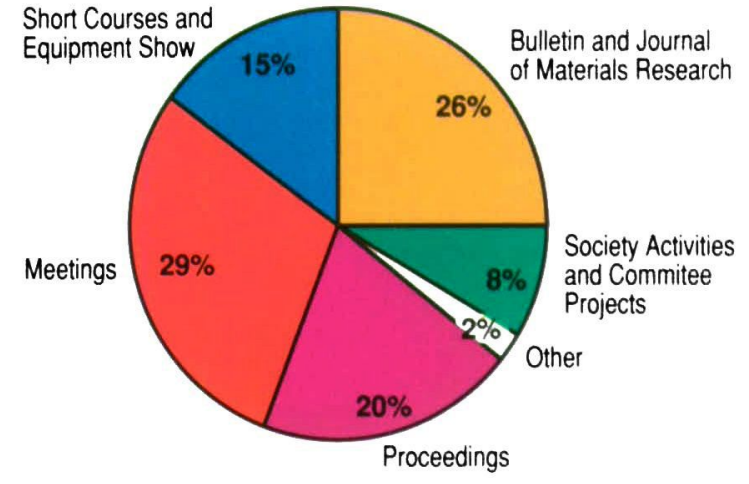

Figure 2. 1987 MRS Expense Categories.

\begin{tabular}{cccc}
\hline \multicolumn{4}{c}{ Table I. Some Key Indicators of MRS Growth } \\
\hline Year & Membership & $\begin{array}{c}\text { Headquarters } \\
\text { Staff }\end{array}$ & $\begin{array}{c}\text { Operating } \\
\text { Budget (\$M)* }\end{array}$ \\
1983 & 1,225 & 0.5 & 0.27 \\
1984 & 2,100 & 3 & 0.52 \\
1985 & 3,550 & 7 & 1.06 \\
1986 & 4,800 & 10 & 1.58 \\
1987 & 5,950 & 15 & 2.01 \\
1988 & 7,770 & 18 & 2.57 \\
\hline
\end{tabular}

"Operating budget (expenses) approved by Council. Actual revenues and expenditures are slightly different.

\begin{tabular}{|c|c|c|c|c|}
\hline \multicolumn{5}{|c|}{$\begin{array}{c}\text { Materials Research Society } \\
\text { Balance Sheets as of December 31, } 1987 \text { and } 1986\end{array}$} \\
\hline \multicolumn{5}{|c|}{ ASSETS } \\
\hline $\begin{array}{l}\text { Current Assets: } \\
\text { Cash and Investments } \\
\text { General Operations } \\
\text { Council Designated* } \\
\text { Accounts Receivable } \\
\text { Grants Receivable } \\
\text { Book Inventory } \\
\text { Prepaid Expenses } \\
\text { Payroll Advances Receivable }\end{array}$ & $\$$ & $\begin{array}{r}1987 \\
\\
912,241 \\
417,819 \\
158,090 \\
147,115 \\
242,427 \\
7,802 \\
546 \\
\end{array}$ & $\$$ & $\begin{array}{r}1986 \\
643,413 \\
400,000 \\
130,641 \\
105,175 \\
142,999 \\
4,755 \\
746 \\
\end{array}$ \\
\hline Total Current Assets & $\overline{\$}$ & $1,886,040$ & $\overline{\$}$ & $1,427,729$ \\
\hline $\begin{array}{l}\text { Property and Equipment: } \\
\text { Furniture and Equipment } \\
\text { Less: Accumulated Depreciation }\end{array}$ & $\$$ & $\begin{array}{r}184,319 \\
77,796 \\
\end{array}$ & $\$$ & $\begin{array}{r}137,365 \\
45,034 \\
\end{array}$ \\
\hline Net Property and Equipment & $\$$ & 106,523 & $\$$ & 92,331 \\
\hline Total Assets & $\$$ & $1,992,563$ & $\$$ & $1,520,060$ \\
\hline \multicolumn{5}{|c|}{ LIABILITIES AND FUND BALANCE } \\
\hline $\begin{array}{l}\text { Current Liabilities: } \\
\text { Accounts Payable } \\
\text { Accrued Payroll Taxes } \\
\text { Other Accrued Expenses } \\
\text { Deferred Revenue }\end{array}$ & $\$$ & $\begin{array}{r}140,293 \\
2,104 \\
147,215 \\
179,459\end{array}$ & $\$$ & $\begin{array}{r}176,970 \\
9,476 \\
- \\
147,760\end{array}$ \\
\hline $\begin{array}{c}\text { Total Current Liabilities } \\
\text { Fund Balance (Unrestricted) } t\end{array}$ & $\$$ & $\begin{array}{r}469,071 \\
1,523,492 \\
\end{array}$ & $\$$ & $\begin{array}{r}334,206 \\
1,185,854 \\
\end{array}$ \\
\hline Total Liabilities and Fund Balance & $\$$ & $1,992,563$ & $\$$ & $1,520,060$ \\
\hline
\end{tabular}

\begin{tabular}{lrrr}
\hline \multicolumn{1}{c}{ Materials Research Society } \\
Statements of Revenues, Expenses, and Changes in Fund Balance \\
for the Years Ended December 31,1987 and 1986
\end{tabular}

